\title{
P. HUDEC
}

\section{ANALYSIS OF ACCURACY OF DIGITAL ELEVATION MODELS CREATED FROM CAPTURED DATA BY DIGITAL PHOTOGRAMMETRY METHOD}

Peter HUDEC
email: peto.hudec@gmail.com
Research field: digital elevation model, thematic maps
for flood prevention, geographic information system
Department of Mapping and Land Consolidation
Faculty of Civil Engineering,
Slovak University of Technology in Bratislava,
Radlinského 11
81368 Bratislava

\author{
INFORMATION
}

\begin{abstract}
A digital elevation model (DEM) is an important part of many geoinformatic applications. For the creation of DEM, spatial data collected by geodetic measurements in the field, photogrammetric processing of aerial survey photographs, laser scanning and secondary sources (analogue maps) are used. It is very important from a user's point of view to know the vertical accuracy of a DEM. The article describes the verification of the vertical accuracy of a DEM for the region of Medzibodrozie, which was created using digital photogrammetry for the purposes of water resources management and modeling and resolving flood cases based on geodetic measurements in the field.
\end{abstract}

\section{KEY WORDS}

\section{INTRODUCTION}

Detailed knowledge of the relief of the Earth through a digital elevation model (DEM) is one of the essential presumptions for mathematical modeling of the course of water level elevations under flood simulation and subsequently for its creation with related space analysis. The quality of a DEM is not only subject to the density and space distribution of entry points and the choice of the method of space data collection, but also to the interpolation method selected and the purpose of the application. From a user's point of view it is an important connection for the accuracy required of a DEM and the financial resources invested in its creation.

\section{CHARACTERIZATION OF THE AREA OF INTEREST}

The area of interest is located in the southeast of the Slovak Republic in the region of Košice; the operative part of the area is in the southern section of the district of Trebišov. The area of concern is Medzibodrožie, which is delimited by the river Latorica on the north, the Slovak-Ukrainian border on the east, the Slovak-Hungarian border on the south and the river Bodrog on the west (Fig. 1). The area is flat; it is an intensively utilized agricultural region with a relatively dense network of dead stream branches, sloppy terrain depressions, channels and alluvial meadows. Surrounding the rivers are relatively well preserved floodplain forests. The total land area is approximately $400 \mathrm{~km}^{2}$.

\section{ENTRY DATA FOR DEM}

Data was applied in the creation of the DEM for the purpose of examining its quality in terms of flood prevention - vertical points and terrain edges, which were processed using aerial survey photographs (ASP) of the area of interest from the years 2002 and 2007. 


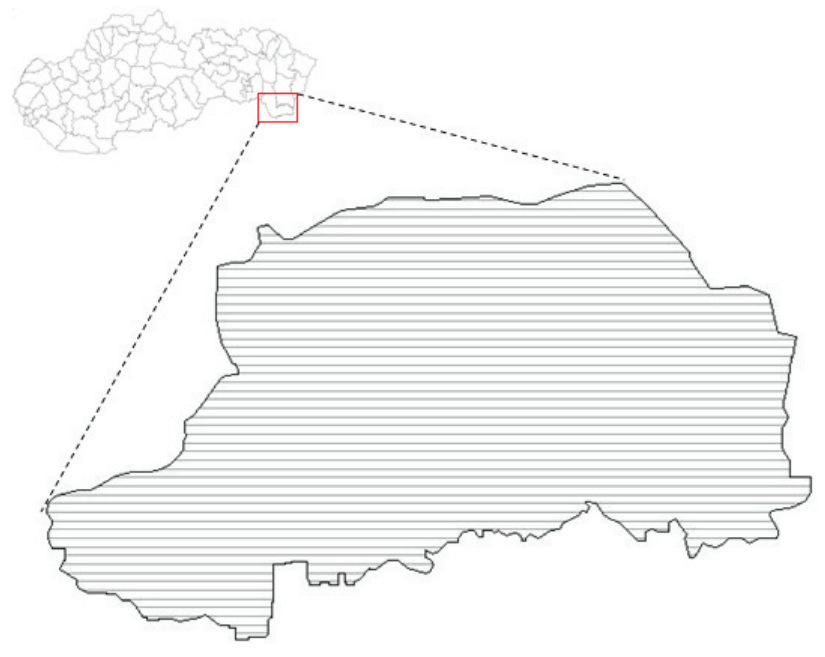

Fig. 1 Boundaries of area of interest.

The entire process of the collection and processing of entry data for the needs of a DEM was realized by GEODIS SLOVAKIA, s.r.o., using digital photogrammetry techniques. The data was primarily intended for solving the project "Development of a common concept of land and water management, examination of the options for its realization and projecting particular elements of the concept at Medzibodrožie, which was realized within the framework of a community initiative program called INTERREG IIIA, a program for the region of Hungary - Slovakia - Ukraine 2004-2006 and for purposes of flood prevention projects.

The aerial metrical photographs from the year 2002 are true-toscale of 1:8000 and cover the whole area of interest (see Fig. 1). According to Šrámková (2007), the accuracy of the DEM processed in an area not covered with vegetation is characterized by a standard vertical error $m_{z} \leq 0.35 \mathrm{~m}$. These records were applied for the purposes of the INTERREG IIIA project as a homogenous current record of the whole area and for more accurate area specifications (Fig. 2.), where more quality data for water-management purposes are required.

For establishing the required accuracy of the DEM, which is characterized by a standard vertical error of $\mathrm{m}_{\mathrm{z}} \leq 0.15 \mathrm{~m}$, an additional aerial survey was realized in 2007, the results of which are ASP scales of 1:4500. The LMS covers approximately one half $\left(\mathrm{cca} 200 \mathrm{~km}^{2}\right.$ ) of the area of interest (see Fig. 2).

Before the survey itself, 294 control points in the 3. class of accuracy (TP 3 - CA 3) for detailed points were measured using the Global Positioning System (GPS) method. A survey (846 ASP) was done on 25. - 26.03.2007 on a scale of $1: 4500$ by a CESSNA 206 G plane with the ZEISS LMK - 2015, an integral measuring camera with a focal distance of $150 \mathrm{~mm}$, a forward overlap of $60 \%$

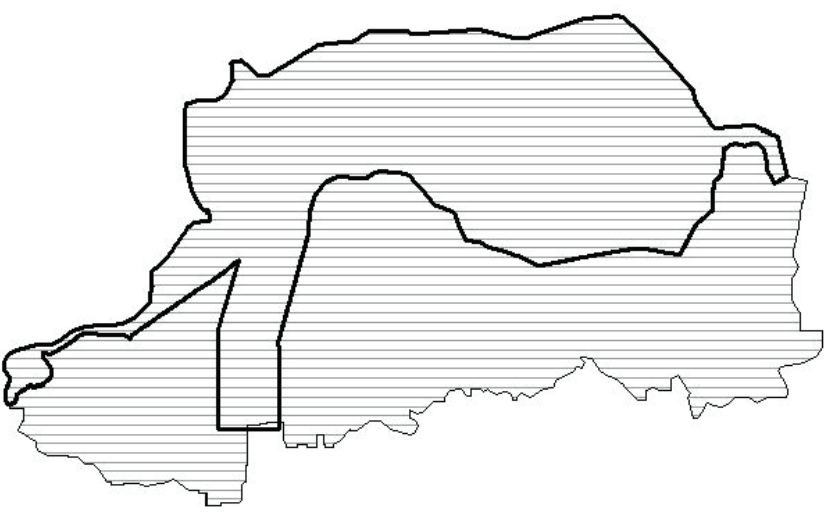

Fig. 2 Spatial definition of the locality of the aerial survey from 2007 within the framework of the area of interest.

and a cross overlap of $30 \%$, through the use of satellite navigation GPS, during suitable meteorological conditions.

For the choice of a suitable survey date there were four basic limiting meteorological conditions:

- cloudless weather in the locality of interest,

- a vegetation period without developing vegetation,

- a locality of interest without snow cover,

- a locality of interest without flooded areas.

The developed films were scanned with a PHOTOCSAN TD photogrammetric scanner with a distinction of 14 micrometers. The quality of the photographs achieved is suitable and standard for this term of taking photographs (Šrámková, 2007).

The measurement and calculation of the analytic aerotriangulation (AAT) were realized using the IMAGESTATION digital photogrammetric station of the INTERGRAPH firm. The calculation of the aerotriangulation was realized with the ISAT balancing program using the independent models method.

On the basis of the ATT calculation the stereoscopic couples were absolutely oriented and stepwise evaluated with a universal method of stereophotogrammetry. The mapping was performed in a MicroStation environment in a 3D shape (Šrámková, 2007).

According to Šrámková (2007), the accuracy of the created DEM is on an area not covered with vegetation and characterized by a standard vertical error $m_{z} \leq 0.15 \mathrm{~m}$.

\section{CREATION OF THE DEM}

For the creation of the DEM from the entry of the photogrammetrically evaluated data (vertical points and terrain edges), we used the 
Surfer 8 program environment from the Golden Software company. We created the DEM from entry data processed from an ASP area of interest of the years 2002 and 2007:

- DEM 2002,

- DEM 2007.

It was not necessary to create a DEM of the whole area of interest for the purposes of the analysis but only on suitable selected localities. Therefore, it considerably shortened the computing time with a course preservation of the DEM. The size of the tested localities was designed so that they exceeded an unequal surface covered with measured control points due to a reliable mutual comparison also on the marginal control points (Fig. 3). A distance of $750 \mathrm{~m}$ was selected as a sufficient overhang.

Regarding the representation and mutual comparison in the creation of the DEM, more interpolating methods were applied, which respect the terrain's edges by interpolation (Kriging, Local Polynomials Method and Radial Basis Functions Method) as well as methods by which the application of a terrain's edges is impossible (Natural Neighbor Method and Triangulation with the Linear Interpolation Method). On the same basis a DEM was created with two sizes of the grid $(10 \times 10 \mathrm{~m}$ a $15 \times 15 \mathrm{~m})$ by each interpolating method. The larger the grid density, the more the smoothing of the relief increases as well as the time of the interpolation and the data size of the final data file. With the interpolation alone the quality of the DEM is affected by, in addition to the entry data and the interpolating method, optional parameters that are provided by particular interpolating methods. On the basis that each of the selected methods enables the setting of other specific parameters, we decided to interpolate using only software default interpolating parameters. So the same initial conditions within the Surfer 8 software were provided.

\section{ANALYSIS OF THE ACCURACY OF THE DEM}

The subject of the analysis was an examination of the vertical accuracy of a DEM created out of two data sources using additional interpolation methods and two different grid sizes, by considering the group of control points achieved through direct geodetic measurement.

We realized control of the geodetic measurement in three localities (see Fig. 4) using the geodetic method of electronic tachymetry on 28th and 29th January 2008. A Leica TC 800 electronic total station was used. The manufacturer provided an angle accuracy of $10^{\text {cc }}$ and a length accuracy of $2 \mathrm{~mm}+2 \mathrm{ppm}$ (parts per million). For the measurements we used points of the State space network (SSN) existing in selected localities. The subjects of the measurement were relief points located on profiles and terrain edges.

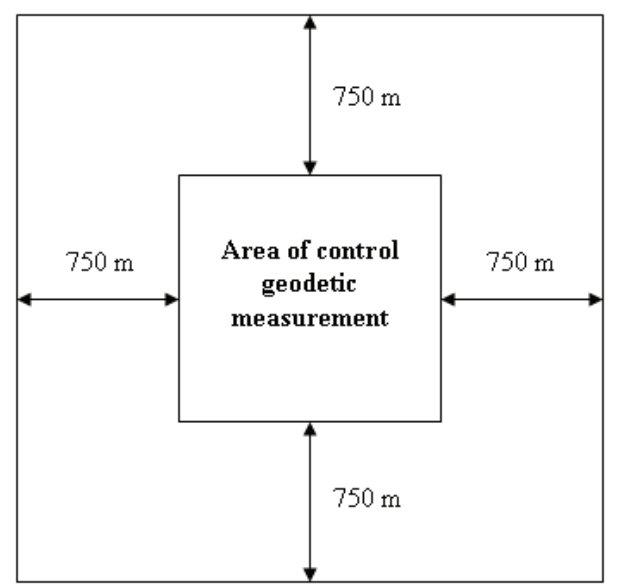

Fig. 3 Area of control of the geodetic measurement within the tested locality.

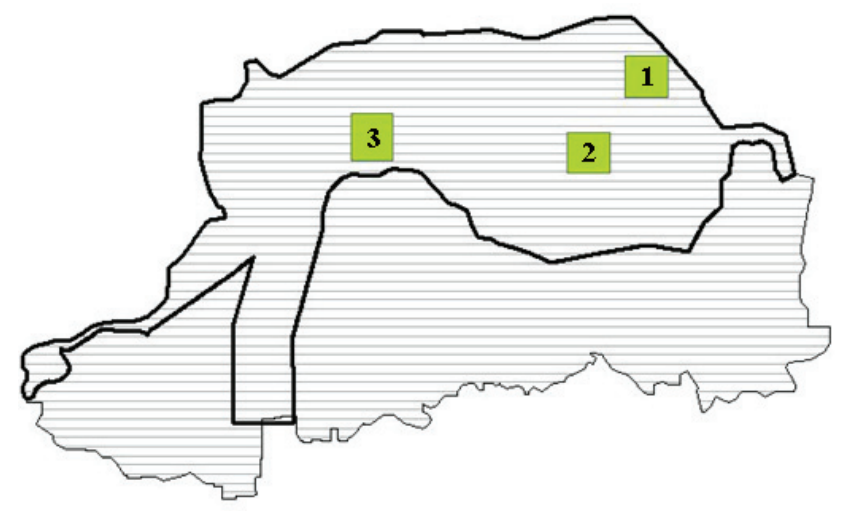

Fig. 4 Test localities within the area of interest.

In the test localities a total of 342 control points together were measured (Locality No. $1-89$ points, No. 2 - 99 points, No. $3-154$ points). The point's coordinates in the planar coordinates system of The Uniform Trigonometric Cadastral Network (S-JTSK) and in the Balt after adjustment of the (Bpv) level system was calculated from the measured data in the KOKEŠ v. 6.70 program environment. The spatial arrangement of the control points is on the graph in figures $5 \mathrm{a}, \mathrm{b}, \mathrm{c}$.

We judged the vertical accuracy of the DEM on the basis of the actual vertical differences of the control point's sea levels and appertained the interpolated heights from the DEM. For calculating the vertical differences we applied the Residuals function in the Surfer program environment (Golden Software, 2002).

If $\mathrm{H}_{\mathrm{CP}}$ are the sea levels of the control points and their accuracy is several times higher than the interpolated sea levels $\mathrm{H}_{\mathrm{DEM}}$, we receive real errors from their difference $\Delta$ : 


\section{IDYALS JOUSSILL \\ 0,

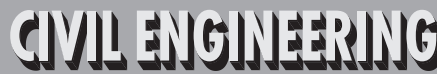

2011/4 PAGES $28-36$

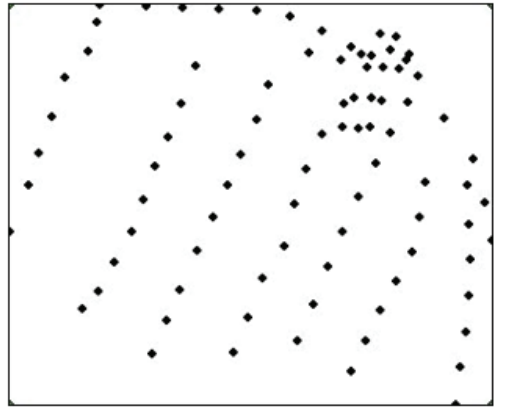

Fig. 5 a Spatial arrangement of control points in tested localities Locality No.1.

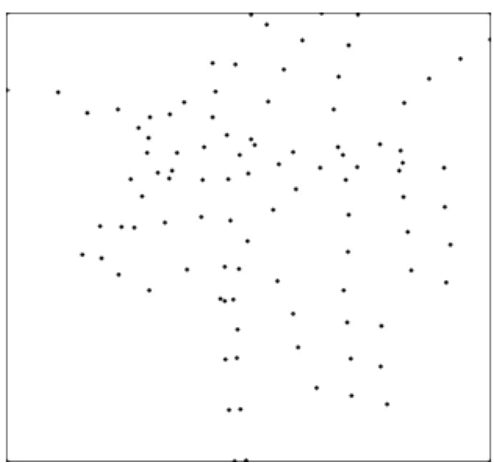

Fig. 5 b Spatial arrangement of control points in tested localities Locality No.2.

$$
\Delta=H_{C P}-H_{D E M}
$$

On the basis of the real errors $\Delta$ we calculated the characterizations of the DEM's accuracy:

- standard error of the height of the relief points

$m_{z}= \pm \sqrt{\frac{\sum_{i=1}^{n} x_{i}^{2}}{n}}$

where: $n$ - number of control points of the given set,

$x_{\mathrm{i}}$ - individual rate of the measured phenomenon,

- dispersion

$\sigma^{2}=\frac{1}{n} \sum_{i=1}^{n}\left(x_{i}-\bar{x}\right)^{2}$

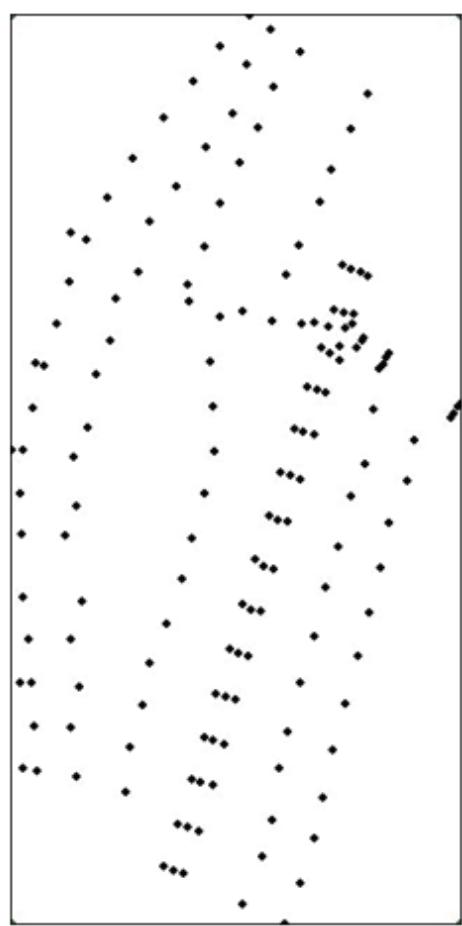

Fig. 5 c Spatial arrangement of control points in tested localities Locality No.3.

where: $n$ - number of control points of the given set,

$x_{\mathrm{i}}$ - individual rate of the measured phenomenon,

$\bar{x}$ - arithmetic average of the measured phenomenon,

- standard deviation

$\sigma=\sqrt{\frac{1}{n} \sum_{i=1}^{n}\left(x_{i}-\bar{x}\right)^{2}}$

where: $n$ - number of control points of the given set,

$x_{\mathrm{i}}$ - individual rate of the measured phenomenon,

$\bar{x}$ - arithmetic average of the measured phenomenon,

- variation interval

$R=x_{\max }-x_{\min }$

where: $x_{\max }-$ maximal rate of the data file,

$\mathrm{x}_{\min }-$ minimal rate of the data file.

The characteristics of the accuracy of a particular DEM are stated in Tables 1 (a, b, c ,d ,e, f, g, h, i, j, k, l). 
Tab. $1 a, b, c, d, e, f, g, h, i, j, k, l$ Characteristics of the accuracy of the created DEM. a.

\begin{tabular}{|l|c|c|c|c|c|}
\hline Locality No. 1, DEM 2002, grid $10 \times \mathbf{~} \mathbf{1 0} \mathbf{~ m}$ & $\begin{array}{c}\text { Arithmetic } \\
\text { average }[\mathbf{m}]\end{array}$ & $\begin{array}{c}\text { Variation } \\
\text { interval } \mathbf{R}[\mathbf{m}]\end{array}$ & $\begin{array}{c}\text { Dispersion } \\
\mathbf{\sigma}^{\mathbf{2}}\left[\mathbf{m}^{\mathbf{2}}\right]\end{array}$ & $\begin{array}{c}\text { Standard } \\
\text { deviation } \boldsymbol{\sigma}[\mathbf{m}]\end{array}$ & $\begin{array}{c}\text { Standard error of height } \\
\text { of relief points } \mathbf{m}_{\mathbf{Z}}[\mathbf{m}]\end{array}$ \\
\hline Kriging & -0.07 & 2.38 & 0.10 & 0.31 & 0.32 \\
\hline Local polynomial & 0.07 & 3.55 & 0.47 & 0.69 & 0.69 \\
\hline Natural neighbor & 0.32 & 3.53 & 0.77 & 0.88 & 0.93 \\
\hline Radial basis functions & -0.27 & 5.66 & 0.67 & 0.82 & 0.86 \\
\hline Triangul. with linear interpolation & 0.32 & 3.52 & 0.76 & 0.87 & 0.93 \\
\hline
\end{tabular}

b.

Locality No. 2, DEM 2002, grid 10 x 10 m

\begin{tabular}{|l|c|c|c|c|c|}
\hline Method of interpolation & $\begin{array}{c}\text { Arithmetic } \\
\text { average }[\mathbf{m}]\end{array}$ & $\begin{array}{c}\text { Variation } \\
\text { interval } \mathbf{R}[\mathbf{m}]\end{array}$ & $\begin{array}{c}\text { Dispersion } \\
\boldsymbol{\sigma}^{\mathbf{2}}\left[\mathbf{m}^{\mathbf{2}}\right]\end{array}$ & $\begin{array}{c}\text { Standard } \\
\text { deviation } \boldsymbol{\sigma}[\mathbf{m}]\end{array}$ & $\begin{array}{c}\text { Standard error of height } \\
\text { of relief points } \mathbf{~}_{\mathbf{Z}}[\mathbf{m}]\end{array}$ \\
\hline Kriging & 0.13 & 2.88 & 0.14 & 0.37 & 0.39 \\
\hline Local polynomial & 0.35 & 2.72 & 0.34 & 0.58 & 0.68 \\
\hline Natural neighbor & 0.35 & 2.41 & 0.20 & 0.44 & 0.56 \\
\hline Radial basis functions & 0.06 & 4.21 & 0.28 & 0.53 & 0.53 \\
\hline Triangul. with linear interpolation & 0.34 & 2.52 & 0.20 & 0.45 & 0.57 \\
\hline
\end{tabular}

c.

\begin{tabular}{|l|c|c|c|c|c|}
\hline Locality No. 3, DEM 2002, grid $\mathbf{1 0} \times \mathbf{~} \mathbf{1 0} \mathbf{~ m}$ \\
\hline Method of interpolation & $\begin{array}{c}\text { Arithmetic } \\
\text { average }[\mathbf{m}]\end{array}$ & $\begin{array}{c}\text { Variation } \\
\text { interval } \mathbf{R}[\mathbf{m}]\end{array}$ & $\begin{array}{c}\text { Dispersion } \\
\boldsymbol{\sigma}^{\mathbf{2}}\left[\mathbf{m}^{\mathbf{2}}\right]\end{array}$ & $\begin{array}{c}\text { Standard } \\
\text { deviation } \boldsymbol{\sigma}[\mathbf{m}]\end{array}$ & $\begin{array}{c}\text { Standard error of height } \\
\text { of relief points } \mathbf{~}_{\mathbf{Z}}[\mathbf{m}]\end{array}$ \\
\hline Kriging & 0.25 & 1.68 & 0.09 & 0.30 & 0.39 \\
\hline Local polynomial & 0.74 & 4.49 & 1.48 & 1.22 & 1.42 \\
\hline Natural neighbor & 0.81 & 3.20 & 0.76 & 0.87 & 1.19 \\
\hline Radial basis functions & 0.23 & 1.39 & 0.07 & 0.27 & 0.36 \\
\hline Triangul. with linear interpolation & 0.82 & 3.47 & 0.77 & 0.88 & 1.20 \\
\hline
\end{tabular}

d.

\begin{tabular}{|c|c|c|c|c|c|}
\hline \multicolumn{6}{|c|}{ Locality No. 1, DEM 2002, grid 15 x 15 m } \\
\hline Method of interpolation & $\begin{array}{c}\text { Arithmetic } \\
\text { average [m] }\end{array}$ & $\begin{array}{c}\text { Variation } \\
\text { interval } R[\mathrm{~m}]\end{array}$ & $\begin{array}{c}\text { Dispersion } \\
\sigma^{2}\left[\mathrm{~m}^{2}\right]\end{array}$ & $\begin{array}{c}\text { Standard } \\
\text { deviation } \sigma[\mathrm{m}]\end{array}$ & $\begin{array}{l}\text { Standard error of height } \\
\text { of relief points } m_{z}[\mathrm{~m}]\end{array}$ \\
\hline Kriging & -0.08 & 2.46 & 0.11 & 0.33 & 0.34 \\
\hline Local polynomial & 0.07 & 3.48 & 0.47 & 0.68 & 0.68 \\
\hline Natural neighbor & 0.32 & 3.53 & 0.77 & 0.88 & 0.93 \\
\hline Radial basis functions & -0.18 & 5.31 & 0.49 & 0.70 & 0.72 \\
\hline Triangul. with linear interpolation & 0.32 & 3.52 & 0.77 & 0.87 & 0.93 \\
\hline
\end{tabular}


Tab. $1 a, b, c, d, e, f, g, h, i, j, k, l$ Characteristics of the accuracy of the created DEM.

e.

\begin{tabular}{|l|c|c|c|c|c|}
\hline Locality No. 2, DEM 2002, grid $\mathbf{1 5} \times \mathbf{~} \mathbf{1 5} \mathbf{~ m}$ & $\begin{array}{c}\text { Arithmetic } \\
\text { average }[\mathbf{m}]\end{array}$ & $\begin{array}{c}\text { Variation } \\
\text { interval } \mathbf{R}[\mathbf{m}]\end{array}$ & $\begin{array}{c}\text { Dispersion } \\
\mathbf{\sigma}^{\mathbf{2}}\left[\mathbf{m}^{2}\right]\end{array}$ & $\begin{array}{c}\text { Standard } \\
\text { deviation } \boldsymbol{\sigma}[\mathbf{m}]\end{array}$ & $\begin{array}{c}\text { Standard error of height } \\
\text { of relief } \text { points } \mathbf{~}_{\mathbf{Z}}[\mathbf{m}]\end{array}$ \\
\hline Method of interpolation & 0.17 & 2.61 & 0.14 & 0.37 & 0.41 \\
\hline Local polynomial & 0.35 & 2.70 & 0.34 & 0.58 & 0.68 \\
\hline Natural neighbor & 0.35 & 2.40 & 0.20 & 0.45 & 0.57 \\
\hline Radial basis functions & 0.13 & 3.91 & 0.26 & 0.51 & 0.52 \\
\hline Triangul. with linear interpolation & 0.34 & 2.54 & 0.20 & 0.45 & 0.57 \\
\hline
\end{tabular}

f.

Locality No. 3, DEM 2002, grid 15 x 15 m

\begin{tabular}{|l|c|c|c|c|c|}
\hline Method of interpolation & $\begin{array}{c}\text { Arithmetic } \\
\text { average }[\mathbf{m}]\end{array}$ & $\begin{array}{c}\text { Variation } \\
\text { interval } \mathbf{R}[\mathbf{m}]\end{array}$ & $\begin{array}{c}\text { Dispersion } \\
\boldsymbol{\sigma}^{\mathbf{2}}\left[\mathbf{m}^{\mathbf{2}}\right]\end{array}$ & $\begin{array}{c}\text { Standard } \\
\text { deviation } \boldsymbol{\sigma}[\mathbf{m}]\end{array}$ & $\begin{array}{c}\text { Standard error of height } \\
\text { of relief points } \mathbf{~}_{\mathbf{Z}}[\mathbf{m}]\end{array}$ \\
\hline Kriging & 0.30 & 2.49 & 0.18 & 0.43 & 0.52 \\
\hline Local polynomial & 0.74 & 4.51 & 1.48 & 1.22 & 1.42 \\
\hline Natural neighbor & 0.82 & 3.22 & 0.76 & 0.87 & 1.19 \\
\hline Radial basis functions & 0.29 & 2.49 & 0.18 & 0.42 & 0.51 \\
\hline Triangul. with linear interpolation & 0.82 & 3.39 & 0.77 & 0.88 & 1.20 \\
\hline
\end{tabular}

g.

\begin{tabular}{|l|c|c|c|c|c|}
\hline Locality No. 1, DEM 2007, grid $\mathbf{1 0} \times \mathbf{~} \mathbf{1 0} \mathbf{~ m}$ & $\begin{array}{c}\text { Arithmetic } \\
\text { average }[\mathbf{m}]\end{array}$ & $\begin{array}{c}\text { Variation } \\
\text { interval } \mathbf{R}[\mathbf{m}]\end{array}$ & $\begin{array}{c}\text { Dispersion } \\
\boldsymbol{\sigma}^{\mathbf{2}}\left[\mathbf{m}^{\mathbf{2}}\right]\end{array}$ & $\begin{array}{c}\text { Standard } \\
\text { deviation } \boldsymbol{\sigma}[\mathbf{m}]\end{array}$ & $\begin{array}{c}\text { Standard error of height } \\
\text { of relief points } \mathbf{~}_{\mathbf{Z}}[\mathbf{m}]\end{array}$ \\
\hline Kriging & -0.22 & 2.28 & 0.10 & 0.32 & 0.38 \\
\hline Local polynomial & -0.13 & 3.74 & 0.53 & 0.73 & 0.73 \\
\hline Natural neighbor & -0.12 & 3.78 & 0.41 & 0.64 & 0.65 \\
\hline Radial basis functions & -0.24 & 2.45 & 0.10 & 0.31 & 0.39 \\
\hline Triangul. with linear interpolation & -0.11 & 3.82 & 0.45 & 0.67 & 0.68 \\
\hline
\end{tabular}

h.

Locality No. 2, DEM 2007, grid $10 \times 10 \mathrm{~m}$

\begin{tabular}{|l|c|c|c|c|c|}
\hline Method of interpolation & $\begin{array}{c}\text { Arithmetic } \\
\text { average }[\mathbf{m}]\end{array}$ & $\begin{array}{c}\text { Variation } \\
\text { interval } \mathbf{R}[\mathbf{m}]\end{array}$ & $\begin{array}{c}\text { Dispersion } \\
\boldsymbol{\sigma}^{\mathbf{2}}\left[\mathbf{m}^{\mathbf{2}}\right]\end{array}$ & $\begin{array}{c}\text { Standard } \\
\text { deviation } \boldsymbol{\sigma}[\mathbf{m}]\end{array}$ & $\begin{array}{c}\text { Standard error of height } \\
\text { of relief points } \mathbf{~}_{\mathbf{Z}}[\mathbf{m}]\end{array}$ \\
\hline Kriging & -0.05 & 2.73 & 0.13 & 0.36 & 0.36 \\
\hline Local polynomial & -0.02 & 2.44 & 0.24 & 0.49 & 0.49 \\
\hline Natural neighbor & -0.00 & 2.60 & 0.15 & 0.39 & 0.39 \\
\hline Radial basis functions & -0.13 & 3.76 & 0.23 & 0.48 & 0.49 \\
\hline Triangul. with linear interpolation & -0.01 & 2.63 & 0.16 & 0.40 & 0.40 \\
\hline
\end{tabular}


Tab. $1 a, b, c, d, e, f, g, h, i, j, k, l$ Characteristics of the accuracy of the created DEM.

i.

\begin{tabular}{|l|c|c|c|c|c|}
\hline Locality No. 3, DEM 2007, grid $\mathbf{1 0} \times \mathbf{~} \mathbf{1 0} \mathbf{~ m}$ & $\begin{array}{c}\text { Arithmetic } \\
\text { average }[\mathbf{m}]\end{array}$ & $\begin{array}{c}\text { Variation } \\
\text { interval } \mathbf{R}[\mathbf{m}]\end{array}$ & $\begin{array}{c}\text { Dispersion } \\
\boldsymbol{\sigma}^{\mathbf{2}}\left[\mathbf{m}^{\mathbf{2}}\right]\end{array}$ & $\begin{array}{c}\text { Standard } \\
\text { deviation } \boldsymbol{\sigma}[\mathbf{m}]\end{array}$ & $\begin{array}{c}\text { Standard error of height } \\
\mathbf{o f}_{\text {relief }} \text { points } \mathbf{~}_{\mathbf{Z}}[\mathbf{m}]\end{array}$ \\
\hline Kriging & -0.03 & 1.61 & 0.10 & 0.31 & 0.31 \\
\hline Local polynomial & 0.13 & 4.33 & 1.43 & 1.20 & 1.20 \\
\hline Natural neighbor & 0.17 & 3.28 & 0.51 & 0.71 & 0.73 \\
\hline Radial basis functions & -0.06 & 1.73 & 0.08 & 0.29 & 0.30 \\
\hline Triangul. with linear interpolation & 0.17 & 3.58 & 0.54 & 0.74 & 0.76 \\
\hline
\end{tabular}

j.

Locality No. 1, DEM 2007, grid 15 x 15 m

\begin{tabular}{|l|c|c|c|c|c|}
\hline Method of interpolation & $\begin{array}{c}\text { Arithmetic } \\
\text { average }[\mathbf{m}]\end{array}$ & $\begin{array}{c}\text { Variation } \\
\text { interval } \mathbf{R}[\mathbf{m}]\end{array}$ & $\begin{array}{c}\text { Dispersion } \\
\boldsymbol{\sigma}^{\mathbf{2}}\left[\mathbf{m}^{\mathbf{2}}\right]\end{array}$ & $\begin{array}{c}\text { Standard } \\
\text { deviation } \boldsymbol{\sigma}[\mathbf{m}]\end{array}$ & $\begin{array}{c}\text { Standard error of height } \\
\text { of relief points } \mathbf{~}_{\mathbf{Z}}[\mathbf{m}]\end{array}$ \\
\hline Kriging & -0.24 & 2.77 & 0.13 & 0.35 & 0.43 \\
\hline Local polynomial & -0.14 & 3.78 & 0.52 & 0.72 & 0.73 \\
\hline Natural neighbor & -0.12 & 3.74 & 0.41 & 0.64 & 0.65 \\
\hline Radial basis functions & -0.27 & 2.88 & 0.13 & 0.36 & 0.45 \\
\hline
\end{tabular}

$\mathrm{k}$.

\begin{tabular}{|l|c|c|c|c|c|}
\hline Locality No. 2, DEM 2007, grid $15 \mathbf{x} 15 \mathbf{~ m}$ & $\begin{array}{c}\text { Arithmetic } \\
\text { average }[\mathbf{m}]\end{array}$ & $\begin{array}{c}\text { Variation } \\
\text { interval } \mathbf{R}[\mathbf{m}]\end{array}$ & $\begin{array}{c}\text { Dispersion } \\
\boldsymbol{\sigma}^{\mathbf{2}}\left[\mathbf{m}^{2}\right]\end{array}$ & $\begin{array}{c}\text { Standard } \\
\text { deviation } \boldsymbol{\sigma}[\mathbf{m}]\end{array}$ & $\begin{array}{c}\text { Standard error of height } \\
\mathbf{o f}_{\text {relief }} \mathbf{p o i n t s} \mathbf{~}_{\mathbf{Z}}[\mathbf{m}]\end{array}$ \\
\hline Kethod of interpolation & -0.06 & 2.60 & 0.12 & 0.35 & 0.35 \\
\hline Local polynomial & -0.01 & 2.47 & 0.25 & 0.50 & 0.49 \\
\hline Natural neighbor & -0.00 & 2.29 & 0.14 & 0.38 & 0.38 \\
\hline Radial basis functions & -0.21 & 4.28 & 0.33 & 0.58 & 0.61 \\
\hline Triangul. with linear interpolation & -0.01 & 2.31 & 0.15 & 0.38 & 0.38 \\
\hline
\end{tabular}

1.

Locality No. 3, DEM 2007, grid 15 x 15 m

\begin{tabular}{|l|c|c|c|c|c|}
\hline Method of interpolation & $\begin{array}{c}\text { Arithmetic } \\
\text { average }[\mathbf{m}]\end{array}$ & $\begin{array}{c}\text { Variation } \\
\text { interval } \mathbf{R}[\mathbf{m}]\end{array}$ & $\begin{array}{c}\text { Dispersion } \\
\boldsymbol{\sigma}^{\mathbf{2}}\left[\mathbf{m}^{\mathbf{2}}\right]\end{array}$ & $\begin{array}{c}\text { Standard } \\
\text { deviation } \boldsymbol{\sigma}[\mathbf{m}]\end{array}$ & $\begin{array}{c}\text { Standard error of height } \\
\text { of relief points } \mathbf{~}_{\mathbf{Z}}[\mathbf{m}]\end{array}$ \\
\hline Kriging & 0.00 & 2.43 & 0.18 & 0.42 & 0.42 \\
\hline Local polynomial & 0.12 & 4.40 & 1.44 & 1.20 & 1.20 \\
\hline Natural neighbor & 0.19 & 3.19 & 0.52 & 0.72 & 0.74 \\
\hline Radial basis functions & -0.01 & 2.39 & 0.17 & 0.41 & 0.41 \\
\hline
\end{tabular}


For a DEM created from the data of the year 2002, the accuracy should be characterized according to (Šrámková, 2007) by the standard error of the height $\mathrm{m}_{\mathrm{z}} \leq 0.35 \mathrm{~m}$. However, the best average value $\bar{m}_{Z}$ is $0.37 \mathrm{~m}$, which was achieved using the Kriging interpolating method and a grid size of $10 \times 10$ meters.

By using data from the year 2007 we theoretically should achieve results of a higher quality, but we did not achieve the standard error of a height $m_{z} \leq 0.15 \mathrm{~m}$ given by the manufacturer. The final average value of the standard error of a height $\bar{m}_{Z}$ is by using the Kriging interpolating method and a grid size of $10 \times 10$ meters to $0.35 \mathrm{~m}$, which is almost the same interpolation level as the data of year 2002 .

The complex results of the interpolation of the DEM are in the form of standard errors of a height $\bar{m}_{z}$ shown in tables $2 \mathrm{a}, \mathrm{b}$. Based on these results it seems that the Kriging interpolating method is the most suitable of all the methods used for the creation of a DEM of the area of interest.

\section{CONCLUSIONS}

On the basis of the results achieved we can assert that the vertical accuracy of the DEM 2007 does not achieve the manufacturer's stated degree of accuracy and is mainly influenced by the quality of the entry data. The difference between the calculated and stated accuracy can be caused by the unstable height of the vegetation cover (grass growth), which consequently resulted in an inaccurate photogrammetric evaluation. Inaccurate identification of the terrain edges played a role as well.

In general we could say that the accuracy of the DEM created using digital photogrammetry is affected by the parameters and quality of the aerial metrical pictures taken, the height of the flight, the morphometric characteristics of the model area, the status and type of the vegetation cover as well as the human factor during the photogrammetric evaluation. The testing results also referred to the fact that a DEM created from the same entry data provides differently accurate results for various

Tab. 2 a, b Summary of the results of the interpolation of the DEM. a.

\begin{tabular}{|l|c|c|}
\hline \multirow{2}{*}{ MEM 2002} & Grid $\mathbf{1 0} \mathbf{x} \mathbf{1 0 ~} \mathbf{~}$ & Grid $\mathbf{1 5} \mathbf{x} \mathbf{1 5} \mathbf{~ m}$ \\
\cline { 2 - 3 } & $\begin{array}{c}\text { Average standard error of height of relief } \\
\text { points } \bar{m}_{Z}[\mathbf{m}]\end{array}$ & $\begin{array}{c}\text { Average standard error of height of relief } \\
\text { points } \bar{m}_{Z}[\mathbf{m}]\end{array}$ \\
\hline Kriging & 0.37 & 0.42 \\
\hline Local polynomial & 0.93 & 0.93 \\
\hline Natural neighbor & 0.89 & 0.90 \\
\hline Radial basis functions & 0.58 & 0.58 \\
\hline Triangul. with linear interpolation & 0.90 & 0.90 \\
\hline
\end{tabular}

b.

\begin{tabular}{|c|c|c|}
\hline \multicolumn{3}{|l|}{ DEM 2007} \\
\hline \multirow[b]{2}{*}{ Method of interpolation } & Grid $10 \times 10 \mathrm{~m}$ & Grid $15 \times 15$ m \\
\hline & $\begin{array}{l}\text { Average standard error of height of relief } \\
\text { points } \bar{m}_{Z}[\mathrm{~m}]\end{array}$ & $\begin{array}{l}\text { Average standard error of height of relief } \\
\text { points } \bar{m}_{Z}[\mathrm{~m}]\end{array}$ \\
\hline Kriging & 0.35 & 0.40 \\
\hline Local polynomial & 0.81 & 0.81 \\
\hline Natural neighbor & 0.59 & 0.59 \\
\hline Radial basis functions & 0.39 & 0.49 \\
\hline Triangul. with linear interpolation & 0.61 & 0.60 \\
\hline
\end{tabular}




\section{IIOYASS JOUSSIAL \\ 0)

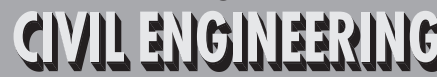

2011/4 PAGES $28-36$

interpolating methods. The effect of the grid size was approved only by using the Kriging interpolating method. From the point of view of a customer it would be suitable and in most cases also necessary that the supplier of the DEM specifies for what kind of software product and interpolation parameters to which the stated accuracy of the DEM is applicable. Otherwise, the supplier could, due to the choice of the inconvenient interpolation parameters, significantly affect any results coming out from the DEM, e.g. the hydrodynamic modelling of a flood level course.

\section{REFERENCES}

[1] GOLDEN SOFTWARE 2002. Surfer 8. User's Guide. Golden: Golden Software, Inc., 2002, 639 pp.

[2] ČULÁKOVÁ, K., OFÚKANÝ, M. 2003. Presnost' digitálneho modelu reliéfu územia PVOD Kočín (The Accuracy of the Digital Terrain Model of the PVOD Kočín Territory). In: Pozemkové úpravy v podmienkach EÚ, Pedagogické listy č. 10/2003, Bratislava: KMPÚ Stavebná fakulta STU $\mathrm{v}$ Bratislave.

[3] OFÚKANÝ, M., KLOBUŠIAK, M. 2004. DMR50 - prvý digitálny model reliéfu Slovenska v rezorte ÚGKK SR (DMR50 - The First Digital Terrain Model of Slovakia in the GCCA SR Sector). In.: Zborník abstraktov z 3. vedecko - odbornej konferencie s medzinárodnou účast'ou, Aktuálne trendy v geodézii, kartografii, geografických informačných systémoch a katastri nehnutel'ností v nových podmienkach Európskej únie, Herl'any.

[4] ŠÍMA, J., EGRMAJEROVÁ, L. 2004. Ověření přesnosti digitálního modelu relief Základní báze geografických dat (Accuracy Testing of Digital Terrain Model of the Fundamental Base of Geographic Data). In: Geodetický a kartografický obzor, č. 11/2004, Prague: Vesmír, pp. 213-231.

[5] ŠRÁMKOVÁ, R. 2007. Technická správa pre licenčnú zmluvu /č. poskytovatel'a: 2007 - 247, č. nadobúdatel'a: 2007 - 01/ (Technical Report for Licence Contract / Supplier's No.: 2007 - 247, Reciever's No.: 2007 - 01/. Banská Bystrica: GEODIS SLOVAKIA, s.r.o., 2007, 16 pp. 